\title{
The Retail Apocalypse as a Critical-Thinking Classroom Exercise
}

\author{
David C. Wyld, Michael C. Budden, and Heather L. Budden
}

\begin{abstract}
One does not have to teach retailing or supply chain management to be aware of the immense changes taking place in retailing. Indeed, the speed at which brick and mortar retailers were folding before the pandemic has only quickened given the impact of the COVID-19 pandemic across the economy. Staying abreast of the retailers and suppliers going out of business has become a challenge. At the same time, educating retailing and supply chain management students on the current and developing market realities in an interesting and educational manner has proven difficult. This article describes a game that can accomplish the goal of providing a meaningful, critical-thinking exercise for classroom use that will elicit student discussion and classroom satisfaction.
\end{abstract}

Index Terms — education; marketing; retailing; teaching.

\section{INTRODUCTION}

The recent past has been tumultuous in retailing. In the last ten years, thousands of stores have shuttered. Before the end of 2019 and before the pandemic began in earnest, major retailers were seemingly announcing closures on a weekly basis. In 2017 alone, over 1,000 stores closed. This trend has been labelled as nothing less than a "tidal wave" movement toward digital and away from brick and mortar stores that has been occurring. And the wave may only grow in intensity, as it has been projected that 75,000 more stores may close by 2026 should online retailing increase its share of retail sales from its current $16 \%$ to $25 \%$ [1].

Of course, as stores close, jobs are lost. Indeed, estimates are that more than 1 million jobs in retailing have been lost since 2010 [2]. Brick and mortar closings are a reality today, and they will likely continue for the foreseeable future. Direct to consumer offerings and fast fashion brands are bypassing brick and mortar stores in the channel of distribution while appeasing customers, and of course, Amazon has broadened and expanded its reach across retailing [3]. As a result of its efforts, Amazon's stock price has increased over 75\% from November 11, 2019 to November 11, 2020. Wal-Mart, which responded better digitally to the pandemic than many stores, saw an increase in stock price of approximately $24 \%$ over the same period. The retail apocalypse of stores who are betting only on brick and mortar may continue.

So, what does this mean for students in supply chain management and marketing? They need to be aware of

Published on December 31, 2020

D. C. Wyld., Southeastern Louisiana University, USA

(corresponding e-mail: dwyld@ ${ }^{\circledR}$ selu.edu)

M.C. Budden, Southeastern Louisiana University, USA.

(e-mail: mbudden@selu.edu)

H. Budden, Southeastern Louisiana University, USA.

(e-mail: Heather.Budden@ selu.edu). which stores are closing, which are surviving, and which are thriving and contemplate on the reason some are thriving. To generate an interest in the retail apocalypse and spur discussion and critical thinking among students, the authors recommend the following class exercise.

Students are aware in general of the move towards digital retailing. Indeed, they often drive it. However, while some recognize the growth of digital sales, many are unaware they are experiencing the downside of the apocalypse in their hometowns. This exercise asks students to identify the year that specific retailers went out of business and the products these businesses sold. For some, the products sold (market) will be easy, for others, not so easy. The year of closure is often a surprise. Indeed, the retailers in this list have all closed in the past 5 years though students are not told that in advance. We utilize a timeline developed by CB Insights [4] highlighting the year of retailers' closure or the year bankruptcy petitions were filed.

\section{THE EXERCISE}

We've all read about the "Retail Apocalypse." In fact, we've all experienced it. Long-time favorite stores might have been here yesterday and literally be gone today (or at least, gone after the ritual "EVERYTHING MUST GO!" liquidation sale).

While the Retail Apocalypse label has stuck as an unfortunate, if unintentional bit of marketing wordsmithing, it is not in truth an entirely accurate identifier of what is taking place in the world of physical retailing today. Rather than a single apocalyptic event - think the business equivalent of a giant meteor or volcanic eruption, the Retail Apocalypse has, in truth, been a slow-rolling, "long march"type event for many retail companies. While there is not a real start date to the Retail Apocalypse, there is also not a foreseeable end date to what is happening either. In fact, it would appear that the events of 2020 - a pandemic induced economic downturn in which consumers have radically shifted their shopping to online and hybrid online shoppingstore pickup or delivery models - has only accelerated the pace of the Retail Apocalypse. In fact, recent research from the analyst firm eMarketer indicates 2020 has ushered in several years' worth of acceleration in the trend toward consumer preference and comfort with online retail shopping [5]. So, as we see one more news story about another retail name declaring bankruptcy and shuttering most or all of its stores, the names and dates tend to blur together. We tend to think of the Retail Apocalypse in the discrete manner that the moniker implies, rather than a long - and sadly still ongoing - event that is reshaping much of the way people shop, work and indeed live in this modern 
age.

And so, with that said, the analyst firm, CB Insights developed a timeline of just how the Retail Apocalypse unfolded - charting the bankruptcies in the retail sector company by company, month by month - graphically depicting the fall of many of retailing's traditional giants and even its upstart firms that fell victim to the changes in the way we shop [4]. The CB Insights report goes into some detail on each of the 117 firms covered in its research, giving background on the retail firm, what went wrong, and where it is - if anywhere - today.

Appreciating the richness of the database that $\mathrm{CB}$ Insights' research produced led us to take their findings and "remix" a part of it as a classroom-based critical thinking exercise. Basically, the exercise is to be utilized as the basis of a fun and engaging classroom exercise for business education in classes on topics including Business Strategy, Marketing, Retailing, Supply Chain Management and Advertising. However, this exercise could just as easily be used as the basis for a parlor game with family, friends, or even coworkers. In either the classroom or the social setting, the challenge will be to play what is, in essence, a "game" based on personal knowledge and recollection of stores as an American consumer - as to when a particular retail company went out of business (just do not use your phone to Google the company!). The challenge is simply this - to remember (guess) the year - each company went bankrupt. And then for extra credit - or to make the task/game even more interesting, players can add another level of difficulty. This second challenge then is to try and remember (yes, it is in essence a trivia game!) for each company the nature of that retailer or in other words, what was their main product line $(s)$ ?

So, for both educational and perhaps even social purposes, the game concerns 21 of the retailers CB Insights included. By using only 21, the game allows for a classroom discussion to take place within the confines of one class period. While CB Insights included retail suppliers and retailers, some of whom had not closed all of their stores, the ones in this list comprise stores which announced they had closed their brick and mortar locations, intended to close them, seek out a buyer, sell its branded merchandise in other venues, or continue as a digital-online operation, with the exception of Brookstone that kept some airport locations open [6]. Like Stage, some may be looking or hoping to find a buyer that can rescue it and breathe in new life [7]. The idea that any of these firms are gone forever may be similar to the often, misquoted statement from Mark Twain, who said, "the report of my death was an exaggeration" [8]. So, while many in this list may be gone forever, some may be resurrected as a brick and mortar entity, a brand sold by another retailer, or as a digital-only retailer.

This engaging exercise/game should provoke interesting discussion and critical thinking in the classroom. Perceived reasons for closure by the students themselves will provoke critical thinking about market relevance, target market satisfaction and trends in retailing. This is precisely because in the past almost six years of the Retail Apocalypse, many familiar retailers and retail products have gone away. Thus, "playing the game" should provoke discussion among students, as well as bring about nostalgic memories for companies and stores, along with the surprising context for exactly when the retailer declared bankruptcy (and even multiple attempts seeking legal bankruptcy protection by many).

So, to begin, here is the alphabetical list of companies: Do not reveal the dates to students. Each listing is followed by a reference to an article that is relevant to the store listed as to that chain's specific demise.

1. A\&P - 2015 [9] [10]

2. Avenue - 2019 [11]

3. Brookstone - 2018 [12] [10]

4. Cache' - 2015 [13] [10]

5. Charming Charlie - 2019 [14] [10]

6. Charlotte Russe - 2019 [15] [10]

7. Fred's - 2019 [16] [10]

8. Gymboree - 2020 [17]

9. Hancock Fabrics - 2019 [18]

10. Joyce Leslie - 2016 [19] [20]

11. The Limited - 2017 [21] [10]

12. Lord \& Taylor - 2020 [22] [23]

13. New York \& Company - 2019 [24]

14. Nine West Holdings - 2020 [[10]

15. Payless - 2020 [25]

16. Pier 1 Imports - 2020 [26]

17. Sports Authority - 2019 [10]

18. Stage Stores - 2020 [7] [27]

19. Toys R Us - 2018 [28]

20. Vanity - 2017 [29]

21. Wet Seal - 2017 [30] [10]

And to ease your use of this list in the classroom setting, here is a "blank" alphabetical listing of the companies for your students to use in choosing the critical year involved for each company:

1. A\&P

2. Avenue

3. Brookstone

4. Cache'

5. Charming Charlie

6. Charlotte Russe

7. Fred's

8. Gymboree

9. Hancock Fabrics

10. Joyce Leslie

11. The Limited

12. Lord \& Taylor

13. New York \& Company

14. Nine West Holdings

15. Payless

16. Pier 1 Imports

17. Sports Authority

18. Stage Stores

19. Toys R Us

20. Vanity

21. Wet Seal.

\section{CONCLUSION}

So how did your students do? What reasons did your students give for these stores' demise? Are any of these stores missed by your students? Hopefully, the pandemic's impact on brick and mortar stores will be brief, and the retail 
apocalypse will soon be only a memory. In the meantime, hopefully this will be a good learning experience and your students can take away lessons as to how to survive the next major change in the retail environment [31].

\section{REFERENCES}

[1] K. Tyko, (December 29, 2019). Retailers lost in the last decade: Toys R Us, Sports Authority, Blockbuster, Borders and Payless. USA Today. Available: https://www.usatoday.com/story/money/2019/12/29/decade-storeclosings-biggest-retailers-lost-decade/2750954001/.

[2] B. Biron, (December 23, 2019). The last decade was devastating for the retail industry. Here's how the retail apocalypse played out. Business Insider. Available: https://www.businessinsider.com/retailapocalypse-last-decade-timeline-2019-12.

[3] C. Russell, (January 13, 2020). The Biggest Retailers We Lost in the 2010s. Forbes. Available: https://www.forbes.com/sites/callyrussell/2020/01/13/the-biggestretailers-we-lost-in-the-2010s/?sh=696ad00823df

[4] CB Insights (October 15, 2020). Research Brief: Here's A List Of 117 Bankruptcies in the Retail Apocalypse and Why They Failed. Available: https://www.cbinsights.com/research/retail-apocalypsetimeline-infographic/.

[5] eMarketer (October 12, 2020). US Ecommerce Growth Jumps to More than $30 \%$, Accelerating Online Shopping Shift by Nearly 2 Years. Available:

https://www.emarketer.com/content/us-ecommerce-growth-jumpsmore-than-30-accelerating-online-shopping-shift-by-nearly-2-years.

[6] M. Wilson, (March 21, 2019). Brookstone emerges from bankruptcy. Chain Store Age. Available: https://chainstoreage.com/finance0/brookstone-emerges-from-bankruptcy.

[7] B. Read, (May 14, 2020). Why Stage Stores closing matter. RetailStrategies.com. Available:

https://www.retailstrategies.com/why-stage-stores-closing-matters/.

[8] E. Petsko, (November 2, 2018). Reports of Mark Twain's quote about his own death are greatly exaggerated. Mentalfloss.com. Available: https://www.mentalfloss.com/article/562400/reports-mark-twainsquote-about-mark-twains-death-are-greatly-exaggerated/.

[9] H. Fitzpatrick, (July 29, 2015). A\&P made one mistake that undermined its business. Business Insider. Available: https://www.businessinsider.com/ap-made-one-mistake-thatundermined-its-business-2015-7.

[10] E. Trattner, (January 2, 2020). The biggest bankruptcies of the retail apocalypse. MoneyWise.com. Available: https://moneywise.com/a/biggest-bankruptcies-retail-apocalypse.

[11] B. Unglesbee and K. Vembar, (November 26, 2019). Avenue Converts Chapter 11 to Chapter 7. Retaildive.com. Available: https://www.retaildive.com/news/avenue-files-for-ch-11-with-plansto-sell-e-commerce-business/561197/.

[12] N. Meyersohn, (August 2, 2018). Brookstone files for bankruptcy and will close all of its mall stores. CNN.com. Available: https://money.cnn.com/2018/08/02/news/companies/brookstonebankruptcy/index.html.

[13] D. Howland, (March 10, 2015). Cache' to close all stores. Retaildive.com. Available: https://www.retaildive.com/news/cache-to-close-all-stores/372570/.

[14] N. Bomey, (July 11, 2019). Charming Charlie going out of business, will close all 261 stores in Chapter 11 bankruptcy. USA Today. Available:

https://usatoday.com/story/money/2019/07/11/charming-charlie-storeclosures-chapter-11-bankruptcy/1702124001.

[15] K. Tyko, (March 6, 2019). Charlotte Russe is closing all of its stores and has started liquidation sales. USA Today. Available: https://www.usatoday.com/story/money/2019/03/06/charlotte-russebankrupt-retailer-says-its-negotiations-buyer/3084088002.

[16] J. Valinsky, (September 9, 2019). Fred's has filed for bankruptcy and will close its 300 remaining stores. CNN Business. Available: https://www.cnn.com/2019/09/09/business/freds-bankruptcyclosures/index.html.

[17] A. Santoro, (February 22, 2020). If you were sad Gymboree closed, get excited: The chain is back in over 200 locations. MoneyWise.com Available: https://moneywise.com/a/biggest-bankruptcies-retailapocalypse.

[18] B. Farfan, (May 30, 2019). Hancock Fabrics goes out of business. Available: https://www.thebalancesmb.com/hancock-store-closings4031365 .
[19] D. Alexander, (February 5, 2016). All Joyce Leslie stores closing; end-of-business sales start; New Jersey 101.5.

Available: https://nj1015.com/all-joyce-leslie-stores-closings-end-ofbusiness-sales-start/.

[20] PR Newswire (February 10, 2016). Joyce Leslie, Inc. receives approval for a sale of its retail store leases and corporate office. Available: https://www.prnewswire.com/news-releases/joyce-leslieinc-receives-approval-for-a-sale-of-its-retail-store-leases-andcorporate-office-300218187.html.

[21] S. Halzack, (January 6, 2017). The Limited is closing all of its 250 stores. Washington Post. Available: https://www.washingtonpost.com/news/business/wp/2017/01/06/thelimited-is-closing-all-of-its-250-stores/.

[22] M. Lisicky, (August 27, 2020). A 194-year era ends as Lord \& Taylor begins closing sales at all locations. Forbes.com. Available: https://www.forbes.com/sites/michaellisicky/2020/08/27/a-194-yearera-ends-as-lord--taylor-begins-closing-sales-in-all-remaininglocations/?sh=2a85682d299c.

[23] J. Valinsky, (August 27, 2020). Lord \& Taylor is closing all of its stores after 194 years in business. CNN.com. Available: http://www.cnn.com/2020/08/27/business/lord-and-taylor-storeclosures-bankruptcy/.

[24] L. Coleman-Lochner and E. Ronalds-Hannon, (July 19, 2020). New York \& Co. parent preparing bankruptcy that shuts all stores. Bloomberg.com. Available:

https://www.bloomberg.com/news/articles/2020-06-19/new-york-coparent-preparig-bankruptcy-that-shuts-all-stores.

[25] P. Kavilanz, (August 17, 2020). Remember Payless? Shoe seller is back and opening its first US store in November. CNN.com. Available: https://www.cnn.com/2020/08/17.business/paylessrelaunch/index.html.

[26] K. Tyko, (May 19, 2020). Coronavirus store closings: Pier 1 Imports to shutter all stores in bankruptcy, liquidation now underway. USA Today. Available: https://www.usatoday.com/story/money/2020/05/19/pier-1-storesclosing-liquidation-coronavirus-covid-19/5221531002/.

[27] R. Venkat (May 10, 2020). Stage stores files for bankruptcy as pandemic chokes sales. https://www.reuters.com/article/us-stagestores-bankruptcy-idUSKBN22N08P/.

[28] A. Selyukh, (March 14, 2018). Game over for Toys R Us: Chain going out of business. NPR.org. Available:

https://www.npr.org/sections/thetwoway/2018/03/14/592882488/game-over-for-toys-r-us-chain-goingout-of-business.

[29] D. Howland, (March 3, 2017). Vanity declares bankruptcy, will shutter all stores. Retaildive.com. Available: https://www.retaildive.com/news/vanity-declares-bankruptcy-willshutter-all-stores/437365/.

[30] K. Taylor, (January 26, 2017). Teen retailer Wet Seal is closing all of its stores. Business Insider. Available:

https://www.businessinsider.com/wet-seal-is-closing-all-locations2017-1.

[31] CB Insights (April 24, 2018). Surviving the retail apocalypse: The technologies and trends that can help brick-and-mortar thrive again. Available: https://www.cbinsights.com/research/retail-apocalypsesurvival-technology-trends/.

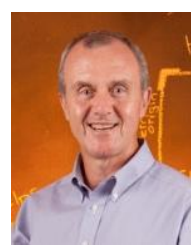

Dr. David C. Wyld received a D.B.A. in Management from the University of Memphis in 1993. Previously, he had earned both an M.B.A. and a B.B.A. from Stephen F. Austin State University in Nacogdoches, Texas in 1985 and 1984, respectively.

He currently serves as the Merritt Professor of Strategic Management at Southeastern Louisiana University in Hammond, Louisiana. Dr. Wyld is the founder and publisher of both Modern Business Press (publishing leading-edge academic journals) and The IDEA Publishing (publishing articles of interest across a wide variety of topics, giving both newbie authors and content marketers a platform for their ideas). As a prolific writer himself, he is a frequent contributor to both respected academic journals and widely read trade and general interest publications. He has established himself as one of the leading academic experts on emerging applications of technology in both the private and public sectors. Dr. Wyld continues to be an active strategic management consultant, a qualified expert witness, and invited speaker on a wide variety of topics to trade, corporate, governmental, and academic audiences.

Dr. Wyld has earned Southeastern's President's Award for both Excellence in Teaching and Research, making him one of a select group of faculty who have been awarded campus-wide recognition for more than one aspect of the professorial role. 


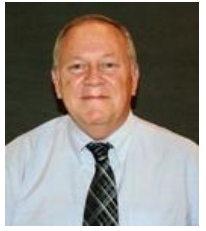

Dr. Michael C. Budden received a Ph.D. in Business Administration from the University of Arkansas (Fayetteville, Arkansas) with a major in marketing in 1982. His MBA was obtained from Southeastern Louisiana University (Hammond, Louisiana) and his BS in finance was earned at Louisiana State University in Baton Rouge, Louisiana.

He is the Benjamin Jones' Professor of Retail Marketing at Southeastern Louisiana University. He served twenty years as a university administrator, 14 of which were in the position of dean of business. Budden's books on trade secrets laws and merchant detention statutes (shoplifting laws) are published by Quorum Books. He has authored/co-authored over 200 articles and paper presentations.

Dr. Budden is a member of the Association for Business Communication. He has served for the past 11 years as University Ombudsperson at Southeastern where he teaches consumer behavior, marketing management and retail management.

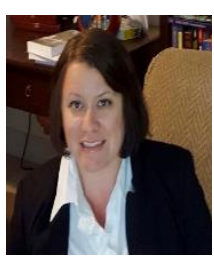

Dr. Heather Budden received a DBA from Louisiana Tech University (Ruston, Louisiana) with a major in Management in 2020. She previously received an MBA and a BA in General Business from Southeastern Louisiana University in Hammond, Louisiana.

She is an instructor in management and an advisor in the Center for Student Excellence at Southeastern. Budden's dissertation dealt with entrepreneurial passion and identity. She has published in the Journal of Managerial Issues and Contemporary Issues in Education Research, among others.

Dr. Budden teaches international management, diversity, and a student success course. Her research interests include entrepreneurship, business education and creativity. 